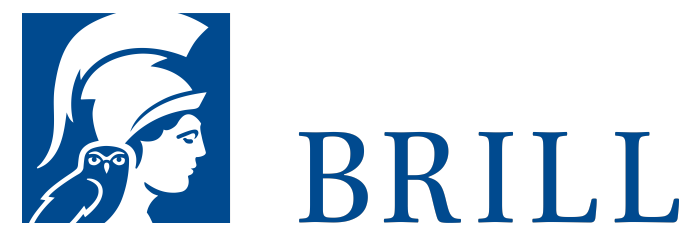

\title{
Functional Structure in Morphology and the Case of Nonfinite Verbs
}

Theoretical Issues and the Description of the Danish Verb System

Author: Peter Juul Nielsen

In this book, Peter Juul Nielsen examines the foundations of morphological theory from a structural-functional perspective on language as a sign system. He offers a framework for the analysis of morpheme relations based on a thorough discussion of syntagmatic and paradigmatic structure, indexical relations, zero as meaningful absence and morphological relations across grammatical categories. It is argued that when paradigmatically related morphological structures have different syntactic functions, the semantics of the paradigmatic opposition consists in the specification of functional potential. The framework is applied in three detailed studies of Danish nonfinite verbs presenting new accounts of their morphological structure, semantic coding and paradigmatic organisation.

Readership

Scholars and students of morphology and grammatical theory with a focus on semantics and functional approaches to linguistic structure. General linguists and students of Germanic and Scandinavian languages and linguistics.

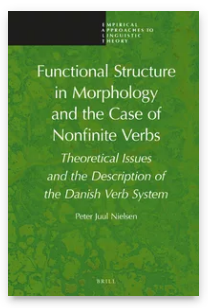

Pages: $x, 440$

pp., index

Language:

English

Subjects:

Morphology \&

Syntax,

Languages and

Linguistics,

Semantics,

Languages and

Linguistics,

Indo-European

Languages,

Languages and

Linguistics

Publisher: Brill

Series:

Empirical

Approaches to

Linguistic

Theory, Volume:

9

E-Book (PDF)

Released online:

10 Jun 2016

ISBN: 978-90-

04-32183-O

List price

USD \$223.00

Hardback

Publication date:

23 Jun 2016 
Peter Juul Nielsen, PhD (2013), Roskilde University, teaches 04-32181-6 List price Danish language at Åbo Akademi University. He has published articles on morphological and syntactic topics and a monograph on the serial verb construction in Danish (Kongruenskonstruktion i dansk, Novus 2011). The research and writing of Functional Structure in Morphology and the Case of Nonfinite Verbs has been carried out while he was Assistant Professor at Roskilde University.

For more information see brill.com

Order information: Order online at brill.com +44330 3330049 | customerservices@brill.com Submission information: brill.com/authors

Titles published by Brill | Fink, Brill | mentis or Brill | Schöningh: +49(o)71 5413279216 | brill@brocom.de 